\title{
Serum Protein and Casein Concentration: Effect on pH and Freezing Point of Milk with Added $\mathrm{CO}_{2}{ }^{1}$
}

Y. Ma and D. M. Barbano

Northeast Dairy Foods Research Center, Department of Food Science,

Cornell University, Ithaca, NY 14853

\section{ABSTRACT}

The objective of this study was to determine the effect of protein concentration and protein type [i.e., casein $(\mathrm{CN})$ and serum protein $(\mathrm{SP})]$ on $\mathrm{pH}\left(0^{\circ} \mathrm{C}\right)$ and freezing point $(\mathrm{FP})$ of skim milk upon $\mathrm{CO}_{2}$ injection at $0^{\circ} \mathrm{C}$. CNfree skim milks with increasing SP content $(0,3$, and $6 \%)$ and skim milks with the same SP content $(0.6 \%)$ but increasing $\mathrm{CN}$ content $(2.4,4.8$, and $7.2 \%)$ were prepared using a combination of microfiltration and ultrafiltration processes. $\mathrm{CO}_{2}$ was injected into milks at $0^{\circ} \mathrm{C}$ using a continuous flow carbonation unit $(230$ $\mathrm{ml} / \mathrm{min}$ ). Increasing SP or CN increased milk buffering capacity and protein-bound mineral content. At the same $\mathrm{CO}_{2}$ concentration at $0^{\circ} \mathrm{C}$, a milk with a higher $\mathrm{SP}$ or a higher $\mathrm{CN}$ concentration had more resistance to $\mathrm{pH}$ change and a greater extent of FP decrease. The buffering capacity provided by an increase of $\mathrm{CN}$ was contributed by both the $\mathrm{CN}$ itself and the colloidal salts solublized into the serum phase from $\mathrm{CN}$ upon carbonation. Skim milks with the same true protein content (3\%), one with $2.4 \% \mathrm{CN}$ plus $0.6 \% \mathrm{SP}$ and one with $3 \%$ $\mathrm{SP}$, were compared. At the same true protein content (3\%), increasing the proportion of $\mathrm{CN}$ increased milk buffering capacity and protein-bound mineral content. Milk with a higher proportion of $\mathrm{CN}$ had more resistance to $\mathrm{pH}$ change and a greater extent of $\mathrm{FP}$ decrease at the same carbonation level at $0^{\circ} \mathrm{C}$. Once $\mathrm{CO}_{2}$ was dissolved in the skim portion of a milk, the extent of $\mathrm{pH}$ reduction and $\mathrm{FP}$ depression depended on protein concentration and protein type (i.e., $\mathrm{CN}$ and SP).

(Key words: carbon dioxide, casein, freezing point, $\mathrm{pH}$, serum protein)

Abbreviation key: CCP = colloidal calcium phosphate; CN2.4, CN4.8, and CN7.2 = skim milks with,

Received August 22, 2002.

Accepted November 20, 2002.

Corresponding author: D. M. Barbano; e-mail: dmb37@cornell.edu.

${ }^{1}$ Use of names, names of ingredients, and identification of specific models of equipment is for scientific clarity and does not constitute any endorsement of products by the authors, Cornell University, or the Northeast Dairy Foods Research Center. respectively, $2.4,4.8$, and $7.2 \%$ casein in the fat-free portion and $0.6 \%$ serum protein in the fat-free, caseinfree portion; FP = freezing point; $\mathbf{M F}=$ microfiltration; $\mathbf{N C N}=$ noncasein nitrogen; $\mathbf{N P N}=$ nonprotein nitrogen; SP $=$ serum protein; $\mathbf{S P 0}, \mathbf{S P 3}$, and $\mathbf{S P 6}=$ skim milks with, respectively, 0,3 , and $6 \%$ serum protein in the fat-free portion and $0 \%$ casein; $\mathbf{T N}=$ total nitrogen; $\mathbf{T P}$ $=$ true protein.

\section{INTRODUCTION}

The addition of low levels of $\mathrm{CO}_{2}$ is used widely in commercial practice to extend the shelf life of cottage cheese due to the ability of low concentrations of $\mathrm{CO}_{2}$ (e.g., $400 \mathrm{ppm}$ ) to inhibit growth of gram-negative spoilage organism and mold (Hotchkiss and Lee, 1996). Added $\mathrm{CO}_{2}$ can effectively control growth of psychrotropic bacteria in raw milk and finished dairy products during refrigerated storage (King and Mabbitt, 1982; Rashed et al., 1986; Hotchkiss et al., 1999). Dissolved $\mathrm{CO}_{2}$ increases the lag phase and generation time of microorganisms (Daniels et al., 1985) due to a direct effect of the $\mathrm{CO}_{2}$ and not due simply to a oxygen displacement. The dairy industry is interested in expanding the use of $\mathrm{CO}_{2}$ technology, seeking applications for shelf life extension in other dairy foods and identifying benefits of $\mathrm{CO}_{2}$ addition other than its antimicrobial effect. In order to find new opportunities to use the $\mathrm{CO}_{2}$ technology in the dairy industry, the impact of $\mathrm{CO}_{2}$ addition on the chemistry of milk components needs to be thoroughly understood.

When $\mathrm{CO}_{2}$ is dissolved in milk, milk $\mathrm{pH}$ decreases (Ma et al., 2001; Ma and Barbano, 2002). Although the antimicrobial effect of $\mathrm{CO}_{2}$ is not $\mathrm{pH}$-dependent (King and Mabbitt, 1982), many dairy processing steps are pH-dependent (Smits and van Brouwershaven, 1980; Corredig and Dalgleish, 1996; Beaulieu et al. 1999). The extent of $\mathrm{pH}$ reduction is related to the amount of $\mathrm{CO}_{2}$ dissolved, hydrated, and protonated in the aqueous phase of a food and, thus, depends on the intrinsic properties of the aqueous phase, such as buffering capacity and initial pH (Gill, 1988; Devlieghere et al., 1998). 
Milk is a buffered system, and the major buffering components are soluble phosphates, colloidal calcium phosphate $(\mathbf{C C P})$, citrate, bicarbonate, and proteins (Srilaorkul et al., 1989; Lucey et al., 1993; Singh et al., 1997). Milk proteins, including both $\mathrm{CN}$ and serum proteins (SP), with their acid and basic side groups, produce a buffering effect. Serum protein, because of its low concentration in milk, contributes relatively less to the buffering capacity of milk compared with $\mathrm{CN}$ (Srilaorkul et al., 1989). At the same $\mathrm{CO}_{2}$ concentration, milk with a higher buffering capacity is expected to exhibit a greater resistance to $\mathrm{pH}$ change. Upon $\mathrm{CO}_{2}$ addition, a decrease in milk $\mathrm{pH}$ is also accompanied by a progressive solublization of CCP and other colloidal salts from casein micelles into the serum phase (Dalgleish and Law, 1989; Gevaudan et al., 1996; Law and Leaver, 1998). The increase in the concentration of solutes in the serum phase of milk, together with carbonic acid $\left(\mathrm{H}_{2} \mathrm{CO}_{3}\right)$ and its dissociation products $\left(\mathrm{H}^{+}\right.$, $\mathrm{HCO}_{3}{ }^{-}$, and $\mathrm{CO}_{3}{ }^{2-}$ ) leads to decreases in milk freezing point (FP; Ma et al., 2001).

Microfiltration (MF) and UF processes have allowed the concentration and separation of milk fat, protein, lactose, and other minor components in milk. The separated $\mathrm{CN}$ and SP retain their native state in milk and have high functionality (Britten and Pouliot, 1996). The processing characteristics of MF and UF concentrated milk have been investigated, especially within the context of cheese making (Brandsma and Rizvi, 1999; Neocleous et al., 2002a, 2002b). In addition, the properties of fluid milk products with modified protein concentration (Quiñones et al., 1997 and 1998) and with CN:SP ratio other than the 4:1 ratio found in typical milk have been studied (Patocka et al., 1993; Beaulieu et al.,1999; Barbano et al., 2000). In order to expand the use of $\mathrm{CO}_{2}$ in the dairy industry and explore the use of $\mathrm{CO}_{2}$ as a possible processing aide, a basic understanding of how milk protein influences $\mathrm{pH}$ decrease and $\mathrm{FP}$ depression of milk with added $\mathrm{CO}_{2}$ is important. Changes in $\mathrm{pH}$ and freezing point of milk and milk concentrates will have impacts on the functionality of milk during subsequent thermal, freezing, or fermentation processes that may be beneficial in some cases and problematic in others. The objective of this study was to measure the effect of protein concentration and protein type (i.e., $\mathrm{CN}$ and $\mathrm{SP})$ on $\mathrm{pH}\left(0^{\circ} \mathrm{C}\right)$ and $\mathrm{FP}$ of skim milk upon $\mathrm{CO}_{2}$ injection at $0^{\circ} \mathrm{C}$.

\section{MATERIALS AND METHODS}

\section{Milk Formulation}

Microfiltration and ultrafiltration. Each replication was completed in a 6-d period. On d 1, raw skim milk (800 kg, Cornell Dairy plant) was HTST $\left(74^{\circ} \mathrm{C}\right.$ for 16s), pasteurized, and fractionated using a pilot scale, uniform transmembrane pressure MF system (Tetra Alcross M7 Pilot Plant Type, Tetra Pak, Denmark). The MF system was equipped with ceramic Membralox membranes with a nominal pore diameter of $0.1 \mu \mathrm{m}$ and an effective surface area of $1.7 \mathrm{~m}^{2}$. The MF process was carried out at $50^{\circ} \mathrm{C}$ with a transmembrane pressure of 0.22 to 0.28 bar. The inlet retentate pressure was approximately 4.2 bar, and outlet pressure was 2.3 bar. The flow rates of permeate and retentate were 90 and 45 l/h, respectively. For $5 \mathrm{~h}$ continuously, the MF system produced a $3 \mathrm{X}$ retentate that was used directly in milk formulation on $d 4$ and a permeate that was further processed using a UF system on $d 2$.

On $\mathrm{d} 2$, permeate from the MF process was fractionated at $49^{\circ} \mathrm{C} \pm 3^{\circ} \mathrm{C}$ in a plate-and-frame UF system (model Dorr-Oliver Iopor Series 'S'; Amicon, Beverley, MA) to achieve a final SP concentration of about 10 to $11 \%$. The UF system was equipped with $21 \mathrm{~S}-10$ polysulfone membrane plates with a mean molecular weight cutoff of 10,000 Da and an effective surface area of 0.067 $\mathrm{m}^{2}$ per plate. The UF inlet pressure was $3.1 \mathrm{bar}$, and outlet pressure was 1.1 bar.

Formulation and batching. Five ingredients were used to formulate milks of different protein concentration and protein type: MF retentate from skim milk, UF retentate from MF permeate, UF permeate from MF permeate, raw cream from the same batch of whole milk as the skim milk used for MF on d 1, and lactose (Lactose monohydrate TG 207, EM Industries, Inc., NJ; $5 \%$ moisture). Composition analysis of the above ingredients, except lactose, was completed on $d 3$.

The MF retentate, the UF retentate and UF permeate from MF permeate, and the raw cream were analyzed for TS (AOAC, method number 990.20; 33.2.44), fat (AOAC, method number 989.05; 33.2.26 for milk; AOAC, method number 995.18; 33.3 .18 for cream; and Marshall, 1993, number 15.8B for skim milk), lactose (AOAC, method number 984.15; 33.2.24), total nitrogen (TN; AOAC, method number 991.20; 33.2.11), and nonprotein nitrogen (NPN; AOAC, method number 991.21; 33.2.12). Noncasein nitrogen (NCN; AOAC, method number $998.05 ; 33.2 .64)$ was analyzed for the MF retentate and the raw cream. For the UF retentate and UF permeate from MF permeate, NCN was assumed to be equivalent to $\mathrm{TN}$ because no $\mathrm{CN}$ was present (based SDS-PAGE, data not shown). All nitrogen results were expressed as a protein equivalent using a conversion factor of 6.38. True protein (TP) and CN were calculated as $(\mathrm{TN}-\mathrm{NPN}) \times 6.38$ and $(\mathrm{TN}-\mathrm{NCN}) \times 6.38$, respectively. SP was calculated as the difference between TP and $\mathrm{CN}$, and for the UF retentate and UF permeate from $\mathrm{MF}$ permeate, $\mathrm{SP}$ was equal to $\mathrm{TP}$ (i.e., $\mathrm{CN}=0 \%$ ). 
Table 1. The ANOVA models used for the analysis of $\mathrm{pH}\left(0^{\circ} \mathrm{C}\right)$ and freezing point (FP) data for experiments 1 and 2.

\begin{tabular}{|c|c|c|c|c|}
\hline Independent variable & $\mathrm{df}$ for $\mathrm{pH}$ & df for FP & Analyzed as & Error term \\
\hline Replicate & 1 & 1 & Block & \\
\hline Treatment $^{1}$ & 2 & 2 & Fixed effect & Replicate $\times$ treatment \\
\hline Replicate $\times$ treatment & 2 & 2 & Interaction & \\
\hline $\mathrm{CO}_{2}$ linear & 1 & 1 & Continuous variable & $\mathrm{E}$ \\
\hline $\mathrm{CO}_{2}$ quadratic & 1 & $\ldots$ & Continuous variable & $\mathrm{E}$ \\
\hline $\mathrm{CO}_{2}$ linear $\times$ treatment & 2 & 2 & Interaction & $\mathrm{E}$ \\
\hline $\mathrm{CO}_{2}$ quadratic $\times$ treatment & 2 & & Interaction & $\mathrm{E}$ \\
\hline Error $(\mathrm{E})$ & 24 & 27 & & \\
\hline
\end{tabular}

\footnotetext{
${ }^{1}$ For experiment 1 , the treatment is serum protein concentration: 0,3 , and $6 \%$. For experiment 2 , the
} treatment is CN concentration: 2.4, 4.8, and 7.2\%.

On $\mathrm{d} 4$, the compositions of the ingredients were used to calculate the amount of each ingredient needed to achieve the desired level of $\mathrm{CN}, \mathrm{SP}$, and lactose in milks used in the current study. Six batches of milk $(6 \mathrm{~kg}$ each) with different protein composition were prepared on $\mathrm{d} 4$ and stored in 4 -L plastic containers at $4^{\circ} \mathrm{C}$. The actual composition of each milk was confirmed by analysis after preparation. Fat, TS, ash, calcium, and lactose were determined using, respectively, Mojonnier (AOAC, method number 989.05; 33.2.26), oven-drying (AOAC, method number 990.20; 33.2.44), ashing oven (AOAC, method number 945.46; 33.2.10), atomic absorption (Brooks et al., 1970), and enzymatic (AOAC, method number 984.15; 33.2.24) methods. The CN and SP contents were determined by the Kjeldahl methods as described above.

Carbonation and analysis. On d 5, milks were carbonated at 0 to $1^{\circ} \mathrm{C}$ in a lab-scale continuous flow inline $\mathrm{CO}_{2}$ injection system (Ma and Barbano, 2003). At this injection temperature, any milk fat present in the sample would be mostly solid and would not dissolve $\mathrm{CO}_{2}$ (Ma and Barbano, 2003), so any variation in the background fat content of the milk would not influence the results. The injection system was a countercurrent stainless steel tubular heat exchanger (internal diameter $=0.5 \mathrm{~cm}$ ). The entire heat exchanger was cooled by circulating ice water $\left(0\right.$ to $\left.1^{\circ} \mathrm{C}\right)$. Milk was pumped through the system by a peristaltic pump (Amicon LP1 pump, Beverly, MA with Cole-Palmer Masterflex ${ }^{\circledR}$ 7015-81 pump head, Vernon Hills, IL) and $\mathrm{CO}_{2}$ (beverage grade) was injected into milk through a stainless steel tube (internal diameter $=0.08 \mathrm{~cm}$ ) inserted through a Tee-fitting perpendicular to the milk flow immediately after the feed pump. The residence time of the milk in the heat exchanger was approximately $60 \mathrm{~s}$. Six different carbonation levels ranging from 0 (control) to $1800 \mathrm{ppm}$ were achieved by adjusting the flow rate of $\mathrm{CO}_{2}$ while keeping the flow rate of milk constant $(230 \mathrm{ml} / \mathrm{min})$. After carbonation, milk was stored in 40-ml plastic vials (Capitol Vial Corp., Ful- tonville, NY) overnight at 0 to $1^{\circ} \mathrm{C}$ to allow equilibration and analyzed on 6 for $\mathrm{pH}\left(0^{\circ} \mathrm{C}\right), \mathrm{CO}_{2}$ concentration ( $\mathrm{Ma}$ et al., 2001), and FP (AOAC, method number 990.22; 33.2.04). Freezing point was determined using a cryoscope (Model 4D3, Advanced Instruments, Inc., Norwood, MA). Before $\mathrm{pH}$ measurement, milk samples were left in ice water for at least $2 \mathrm{~h}$. The $\mathrm{pH}$ probe (model HA 405 DXK-58/120 combination pH probe; Mettler Toledo, Columbus, $\mathrm{OH}$ ) was calibrated with $\mathrm{pH}$ 7.13 and 4.01 buffers (Fisher Scientific, Fair Lawn, NJ) at 0 to $1^{\circ} \mathrm{C}$.

\section{Experimental Design and Statistical Analysis}

Experiment 1: effect of SP concentration on skim milk $\boldsymbol{p H}$ and $\boldsymbol{F P}$. The effect of SP concentration on $\mathrm{pH}\left(0^{\circ} \mathrm{C}\right)$ and $\mathrm{FP}$ of skim milk with various levels of added $\mathrm{CO}_{2}$ (0 to $1800 \mathrm{ppm}$ ) was determined. The experiment was replicated two times using different batches of fresh milk. Three fat-free (ca., $0 \%$ fat), $\mathrm{CN}$-free $(0 \%$ $\mathrm{CN}$ ) milks with increasing SP concentration (i.e., 0, 3, and $6 \%$ ) were prepared, with the goal of having a constant background concentration of lactose. The three milks were designated as SP0, SP3, and SP6, respectively, and were formulated using only three ingredients: the UF retentate from MF permeate, the UF permeate from MF permeate, and lactose.

Each milk had a target concentration of 5.3\% lactose in its fat-free, CN-free, and SP-free portion. For SP0, which had $0 \%$ fat, $0 \% \mathrm{CN}$, and $0 \% \mathrm{SP}$, its lactose content on a total sample weight basis was equal to $5.3 \%$. The lactose concentrations in SP3 and SP6 on a whole sample weight basis were calculated to be, respectively, 5.3 $\times(100-3) \%=5.14 \%$ and $5.3 \times(100-6) \%=4.98 \%$. Because of the water displacement effect due to the presence of SP, this formulation method kept the lactose concentration the same in the total background water phase of the three milks regardless of their SP concentration in the total sample. Each milk was carbonated at 0 to $1^{\circ} \mathrm{C}$ to contain six different $\mathrm{CO}_{2}$ concen- 
Table 2. Mean $(\mathrm{n}=2)$ composition, initial $\mathrm{CO}_{2}$ concentration, $\mathrm{pH}$ at $0^{\circ} \mathrm{C}$, and freezing point $(\mathrm{FP})$ of the three milks with increasing serum protein (SP) concentration in experiment 1.

\begin{tabular}{lccc}
\hline Parameters & SP0 & SP3 & SP6 \\
\hline $\mathrm{CO}_{2}, \mathrm{ppm}$ & 40 & 38 & 38 \\
$\mathrm{pH}$ at $0{ }^{\circ} \mathrm{C}(\mathrm{lsd}=0.07)$ & $6.74^{\mathrm{c}}$ & $6.87^{\mathrm{b}}$ & $6.94^{\mathrm{a}}$ \\
$\mathrm{FP},{ }^{1}(\mathrm{lsd}=0.046)$ & -0.537 & -0.557 & -0.580 \\
Total solids, \% (lsd = 0.47) & $6.03^{\mathrm{c}}$ & $8.98^{\mathrm{b}}$ & $11.90^{\mathrm{a}}$ \\
Calcium, mg/100 g milk (lsd = 9.6) & $27.6^{\mathrm{c}}$ & $43.9^{\mathrm{b}}$ & $59.2^{\mathrm{a}}$ \\
Ash, \% (lsd = 0.03) & $0.47^{\mathrm{c}}$ & $0.56^{\mathrm{b}}$ & $0.64^{\mathrm{a}}$ \\
$\mathrm{NPN}{ }^{2}, \%(\mathrm{lsd}=0.04)$ & $0.19^{\mathrm{b}}$ & $0.22^{\mathrm{ab}}$ & $0.24^{\mathrm{a}}$ \\
$\mathrm{CN}$ in the fat-free portion, \% & 0.00 & 0.00 & 0.00 \\
$\mathrm{SP}$ in the fat-free, CN-free portion, \% (lsd = 0.14) & $0.05^{\mathrm{c}}$ & $3.02^{\mathrm{b}}$ & $5.98^{\mathrm{a}}$ \\
Lactose in the fat-free, CN-free, and SP-free portion, \% (lsd=0.29) & 5.24 & 5.30 & 5.36 \\
\hline${ }^{\mathrm{a}, \mathrm{b}, \mathrm{c}} \mathrm{M}$ Means within the same row with different superscripts differ $(P<0.05)$. & & \\
${ }^{\circ} \mathrm{H}=$ degrees Hortvet. & & & \\
${ }^{2} \mathrm{NPN}=$ nonprotein nitrogen $\times 6.38$. & &
\end{tabular}

trations ranging from 0 (control) to $1800 \mathrm{ppm}$. The $\mathrm{pH}$ $\left(0^{\circ} \mathrm{C}\right), \mathrm{CO}_{2}$ concentration, and $\mathrm{FP}$ of the three milks were determined.

Experiment 2: effect of CN concentration on skim milk pH and FP. The effect of CN concentration on $\mathrm{pH}\left(0^{\circ} \mathrm{C}\right)$ and $\mathrm{FP}$ of skim milk with various levels of added $\mathrm{CO}_{2}$ (0 to $1800 \mathrm{ppm}$ ) was determined. The experiment was replicated two times using different batches of fresh milk. Three skim (ca., $0 \%$ fat) milks with increasing $\mathrm{CN}$ content in the fat-free portion (i.e., $2.4,4.8$, and $7.2 \%$ ) were prepared. The milks were designated as CN2.4, CN4.8, and CN7.2, respectively, and were formulated using five ingredients: the MF retentate from skim milk, the UF retentate from MF permeate, the UF permeate from MF permeate, the raw cream, and lactose. The MF retentate from skim contained a low concentration of fat (e.g., 0.15 to $0.30 \%$ ). Cream was used as an ingredient to keep the background fat level constant in all treatments. Each milk had a target concentration of $0.60 \% \mathrm{SP}$ in its fat-free and $\mathrm{CN}$-free portion and a target concentration of 5.3\% lactose in its fat-free, $\mathrm{CN}$-free, and SP-free portion. The CN2.4 milk simulated the composition of a typical skim milk. The calculation method used to set the formulation targets for SP and lactose concentrations on a whole sample weight basis in each milk was similar to the method described for experiment 1, except in this case, percent $\mathrm{CN}$ was considered in the calculation. Each milk was carbonated to contain six different $\mathrm{CO}_{2}$ concentrations ranging from 0 (control) to $1800 \mathrm{ppm}$. The $\mathrm{pH}\left(0^{\circ} \mathrm{C}\right), \mathrm{CO}_{2}$ concentration, and $\mathrm{FP}$ of the three milks were determined.

Statistical analysis. When $\mathrm{CO}_{2}$ is injected into cold milk, $\mathrm{CO}_{2}$ does not dissolve in the solid fat portion of the milk, and the extent of $\mathrm{pH}$ reduction is related to the amount of $\mathrm{CO}_{2}$ dissolved in the skim portion of the milk (Ma and Barbano, 2003). Therefore, for data analysis, the concentration of $\mathrm{CO}_{2}$ in each milk was standardized to the concentration of $\mathrm{CO}_{2}$ in the fat-free portion by correcting for fat content, i.e., $\mathrm{CO}_{2}$ in the fatfree portion $=\mathrm{CO}_{2}$ in the whole milk sample/[1 minus (percent fat/100)] (Ma and Barbano, 2003). All of the $\mathrm{CO}_{2}$ concentrations presented in this paper were $\mathrm{CO}_{2}$ concentrations in the fat-free portion of milk.

The ANOVA models used for analysis of data from experiments 1 and 2 are shown in Table 1 . The concentration of $\mathrm{CO}_{2}$ was treated as a continuous variable. A quadratic term of $\mathrm{CO}_{2}$ concentration was included in the ANOVA model for the $\mathrm{pH}$ data but not for the FP data, as suggested from previous research (Ma et al., 2001; Ma and Barbano, 2003). Because the concentration of $\mathrm{CO}_{2}$ was treated as a continuous variable in the ANOVA model (Table 1), any model terms involving $\mathrm{CO}_{2}$ concentration would be correlated. For example, the $\mathrm{CO}_{2}$ linear and the $\mathrm{CO}_{2}$ quadratic or the $\mathrm{CO}_{2}$ quadratic and $\mathrm{CO}_{2}$ quadratic $\times$ treatment would be correlated. Distortion of the ANOVA by multicollinearity of these terms was resolved by centering the $\mathrm{CO}_{2}$ data using a mathematical transformation of the data for $\mathrm{CO}_{2}$ concentration (Glantz and Slinker, 2001). The transformation was done by subtracting the mean $\mathrm{CO}_{2}$ concentration from each of the individual $\mathrm{CO}_{2}$ concentrations and using these "mean-centered" data in the statistical analysis. This type of linear transformation minimized correlation between the model terms involving $\mathrm{CO}_{2}$ concentration but did not alter the mathematical nature of the statistical testing (Glantz and Slinker, 2001).

Regression analysis was used to produce equations to predict $\mathrm{pH}\left(0^{\circ} \mathrm{C}\right)$ and $\mathrm{FP}$ of milks in experiments 1 and 2 at various levels of $\mathrm{CO}_{2}$. A quadratic term of $\mathrm{CO}_{2}$ concentration was used in the regression for $\mathrm{pH}$ but not for FP. For estimation of the regression parameters (i.e., intercepts and slopes), the nontransformed $\mathrm{CO}_{2}$ concentrations were used. All statistical analyses were done using SAS (Version 8.02, 1999-2001). 
Table 3. Sum of squares (SS) and probabilities $(P)$ from the ANOVA of $\mathrm{pH}\left(0^{\circ} \mathrm{C}\right)$ and freezing point $(\mathrm{FP})$ data in experiment 1 . The treatment was serum protein (SP) concentration: 0,3 , and $6 \%$.

\begin{tabular}{|c|c|c|c|c|}
\hline \multirow[b]{2}{*}{ Independent variable } & \multicolumn{2}{|c|}{$\begin{array}{c}\mathrm{pH} \text { at } 0^{\circ} \mathrm{C} \\
\mathrm{SSM}^{1}=3.361 \\
\text { Model } \mathrm{R}^{2}=0.997\end{array}$} & \multicolumn{2}{|c|}{$\begin{array}{c}\text { FP } \\
\text { SSM }=0.0280 \\
\text { Model } \mathrm{R}^{2}=0.997\end{array}$} \\
\hline & $\mathrm{SS}^{2}$ & $P$ & SS & $P$ \\
\hline Replicate & 0.039 & & 0.0024 & \\
\hline Treatment (i.e, SP concentration) & 0.518 & $<0.01$ & 0.0144 & $<0.05$ \\
\hline Replicate $\times$ treatment & 0.002 & & 0.0005 & \\
\hline $\mathrm{CO}_{2}$ linear & 2.415 & $<0.01$ & 0.0099 & $<0.01$ \\
\hline $\mathrm{CO}_{2}$ quadratic & 0.075 & $<0.01$ & & \\
\hline $\mathrm{CO}_{2}$ linear $\times$ treatment & 0.033 & $<0.01$ & 0.0001 & $<0.01$ \\
\hline $\mathrm{CO}_{2}$ quadratic $\times$ treatment & 0.013 & $<0.01$ & & $\cdots$ \\
\hline Error $(\mathrm{E})$ & 0.011 & & 0.0001 & \\
\hline
\end{tabular}

${ }^{1} \mathrm{SSM}=$ Sum squares of model.

${ }^{2} \mathrm{SS}=$ Sum squares of individual factors.

\section{RESULTS AND DISCUSSION}

\section{Experiment 1: Effect of SP Concentration on Skim Milk pH and FP}

Composition. Mean $(\mathrm{n}=2)$ compositions of SP0, SP3, and SP6 are shown in Table 2. The three milks had increasing SP content in the fat-free and $\mathrm{CN}$-free portion but similar lactose content in the fat-free, $\mathrm{CN}$-free, and SP-free portion, and similar FP (Table 2). NPN increased slightly with increasing SP content, but the differences were small (Table 2). A low level of measured SP content $(0.05 \%$, Table 3$)$ in SP0 was probably caused by low molecular weight peptides present in the UF permeate and trace amounts of SP. The calcium present in SP0 was soluble calcium. The increase in calcium with increasing SP content reflected the additional calcium that was bound to SP (Table 2). With every $1 \%$ increase of SP concentration, the concentration of calcium increased about $5.3 \mathrm{mg} / 100 \mathrm{~g}$ milk. A similar level of SP-bound calcium was observed by Britten and Pouliot (1996). Due to increases in calcium and possibly other minerals that were bound to SP, increasing SP also led to an increase in ash content (Table 2).

Without carbonation, the concentration of $\mathrm{CO}_{2}$ in SP0, SP3, and SP6 were similar (Table 2). In the noncarbonated milks, $\mathrm{pH}$ at $0^{\circ} \mathrm{C}$ increased with increasing SP concentration. Without protein, the major buffering components in milk are soluble phosphate $(\mathrm{pKa}=6.6)$ and bicarbonate ( $\mathrm{pKa}=6.4$; Singh et al., 1997).

pH at $\boldsymbol{O}^{\circ} \boldsymbol{C}$. Treatment (i.e., SP concentration) had a significant impact on milk $\mathrm{pH}$ at $0^{\circ} \mathrm{C}$, and the ANOVA terms for treatment $(P<0.01), \mathrm{CO}_{2}$ linear $\times$ treatment $(P<0.01)$, and $\mathrm{CO}_{2}$ quadratic $\times$ treatment $(P<0.01)$ were significant (Table 3 ). The effect of treatment can be seen in Figure 1: at the same $\mathrm{CO}_{2}$ concentration, the extent of $\mathrm{pH}$ reduction was less in milk with a higher

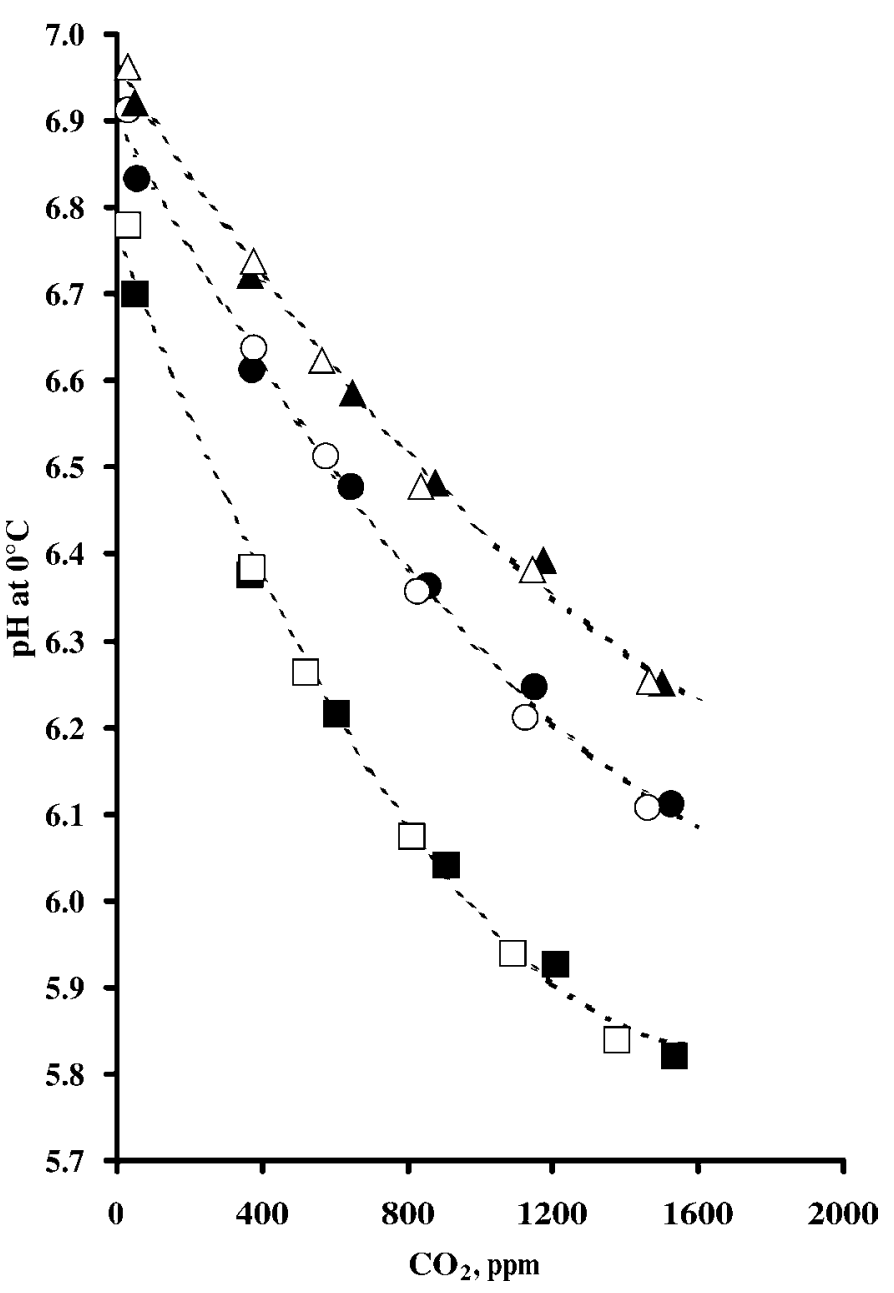

Figure 1. $\mathrm{pH}\left(0^{\circ} \mathrm{C}\right)$ of milks with $0 \%(\boldsymbol{\square}, \square), 3 \%(\bullet, \bigcirc)$, and $6 \%$ $(\boldsymbol{\Delta}, \triangle)$ serum protein upon $\mathrm{CO}_{2}$ addition. The solid and open symbols represent data from replication 1 and 2 , respectively. The dotted lines are the least-square second order polynomial regression lines for each serum protein level. 
Table 4. Regression coefficients for the prediction of $\mathrm{pH}\left(0^{\circ} \mathrm{C}\right)$ and freezing point $(\mathrm{FP})$ upon carbonation for milks with three serum protein (SP) levels (i.e., SP0, SP3, and SP6) and the three casein levels (i.e., CN2.4, CN4.8, and CN7.2). $\mathrm{X}=$ concentration of $\mathrm{CO}_{2}$ in ppm.

\begin{tabular}{|c|c|c|c|c|c|c|}
\hline & \multicolumn{6}{|c|}{ SP } \\
\hline & \multicolumn{3}{|c|}{$\mathrm{pH}$ at $0^{\circ} \mathrm{C}$} & \multicolumn{3}{|c|}{$\mathrm{FP},{ }^{\circ} \mathrm{H}^{1}$} \\
\hline & SP0 & SP3 & SP6 & SP0 & SP3 & SP6 \\
\hline Intercept & 6.77 & 6.90 & 6.96 & -0.5348 & -0.5541 & -0.5763 \\
\hline & $-11.30 \times 10^{-4}$ & $-7.91 \times 10^{-4}$ & $-6.66 \times 10^{-4}$ & $-2.93 \times 10^{-5}$ & $-3.47 \times 10^{-5}$ & $-3.94 \times 10^{-5}$ \\
\hline $\mathrm{X}^{2}$ & $3.40 \times 10^{-7}$ & $1.75 \times 10^{-7}$ & $1.30 \times 10^{-7}$ & $\ldots$ & & \\
\hline \multirow{4}{*}{$\mathrm{R}^{2}$} & 0.99 & 0.99 & 0.99 & 0.98 & 0.99 & 0.99 \\
\hline & \multicolumn{6}{|c|}{ Casein } \\
\hline & \multicolumn{3}{|c|}{$\mathrm{pH}$ at $0^{\circ} \mathrm{C}$} & \multicolumn{3}{|c|}{$\mathrm{FP},{ }^{\circ} \mathrm{H}$} \\
\hline & $\mathrm{CN} 2.4$ & CN4.8 & CN7.2 & CN2.4 & CN4.8 & CN7.2 \\
\hline Intercept & 7.01 & 7.00 & 6.99 & -0.5463 & -0.5572 & -0.5658 \\
\hline & $-7.52 \times 10^{-4}$ & $-5.88 \times 10^{-4}$ & $-4.72 \times 10^{-4}$ & $-4.19 \times 10^{-5}$ & $-4.55 \times 10^{-5}$ & $-4.82 \times 10^{-5}$ \\
\hline $\mathrm{X}^{2}$ & $1.8 \times 10^{-7}$ & $1.17 \times 10^{-7}$ & $0.70 \times 10^{-7}$ & & & \\
\hline $\mathrm{R}^{2}$ & 0.99 & 0.99 & 0.99 & 0.99 & 0.99 & 0.99 \\
\hline
\end{tabular}

${ }^{1}{ }^{\circ} \mathrm{H}=$ degrees Hortvet.

SP concentration. The resistance to $\mathrm{pH}$ change in a higher SP milk demonstrated its higher buffering capacity.

SP0 consisted primarily of water, lactose, and soluble milk salts (Table 2). Thus, the buffering components in SP0 were mainly soluble milk salts, such as phosphate and bicarbonate. Increasing SP concentration to 6\% enhanced the ability of milk to resist $\mathrm{pH}$ change upon $\mathrm{CO}_{2}$ addition at $0^{\circ} \mathrm{C}$ (Figure 1). The increase in the ability of milk to resist $\mathrm{pH}$ change or the increase in buffering capacity was more when SP was increased from 0 to $3 \%$ than when SP was increased from 3 to $6 \%$ (Figure 1). Second-order polynomial regression lines predicting $\mathrm{pH}\left(0^{\circ} \mathrm{C}\right)$ for $\mathrm{SP} 0, \mathrm{SP} 3$, and $\mathrm{SP} 6$ at different $\mathrm{CO}_{2}$ concentrations are plotted in Figure 1, and the regression coefficients are shown in Table 4.

Freezing point. The ANOVA (Table 3) found a significant influence of treatment (i.e., SP concentration) and $\mathrm{CO}_{2}$ linear by treatment interaction, indicating a significant difference in FP depression among SP0, SP3, and $\mathrm{SP} 6$ upon $\mathrm{CO}_{2}$ addition. The decrease in $\mathrm{FP}$ upon $\mathrm{CO}_{2}$ addition was a linear effect, and the impact on FP was greater at a higher SP concentration (Table 4 and Figure 2). In contrast to the direction of $\mathrm{pH}$ change with increasing $\mathrm{SP}$ content, at the same $\mathrm{CO}_{2}$ concentration, the extent of FP decrease was greater in milk with a higher SP content. Regression coefficients shown in Table 4 were calculated using the observed FP. In Figure 2, only the change of FP was plotted, that is, each regression line was shifted to have a zero intercept on the y-axis while keeping the slope the same (Ma et al., 2001). The reason for doing such correction was that only the slope of the regression line or the change of FP was of interest. Increasing SP concentration resulted in a more negative slope for change of $\mathrm{FP}$ upon $\mathrm{CO}_{2}$ addition (Table 4 and Figure 2).

FP is a colligative property of a solution and is directly related to the molality of all the solute particles present in the solution. In SP0, no CN, SP, or protein-bound minerals were present. The FP decrease in SP0 would be contributed by (1) the solublization of $\mathrm{CO}_{2}$ and the dissociation of its hydrated form, carbonic acid $\left(\mathrm{H}_{2} \mathrm{CO}_{3}\right)$ into $\mathrm{H}^{+}, \mathrm{HCO}_{3}{ }^{-}$, and $\mathrm{CO}_{3}{ }^{2-}$ (only trace amount at milk $\mathrm{pH}$ ) and (2) possible increase in soluble solute concentration due to shifts in the degree of association of soluble mineral aggregates. The more negative slopes for FP depression observed for the SP3 and SP6 compared with SP0 (Figure 2 and Table 4) could be due to the release of SP-bound minerals, such as calcium, into the serum phase and an increase in the formation and dissociation of carbonic acid at a constant $\mathrm{CO}_{2}$ concentration.

\section{Experiment 2: Effect of $\mathrm{CN}$ Concentration on Skim Milk pH and FP}

Composition. Mean $(\mathrm{n}=2)$ compositions of CN2.4, CN4.8, and CN7.2 are listed in Table 5. The three milks had increasing $\mathrm{CN}$ concentration but similar SP content (ca. $0.6 \%$ ) in the fat-free, $\mathrm{CN}$-free portion, similar lactose content (ca. 5.25\%) in the fat-free, CN-free, SPfree portion, and similar FP (Table 5). In the CN2.4 milk, the calcium $(104.2 \mathrm{mg} / 100 \mathrm{~g}$ milk) and the ash $(0.71 \%)$ contents were comparable to those of skim milk (Swaisgood, 1985). As would be expected, increasing $\mathrm{CN}$ content resulted in an increase in calcium and ash content in milk (Table 5). For every $1 \%$ increase of $\mathrm{CN}$ concentration, the concentration of calcium increased 


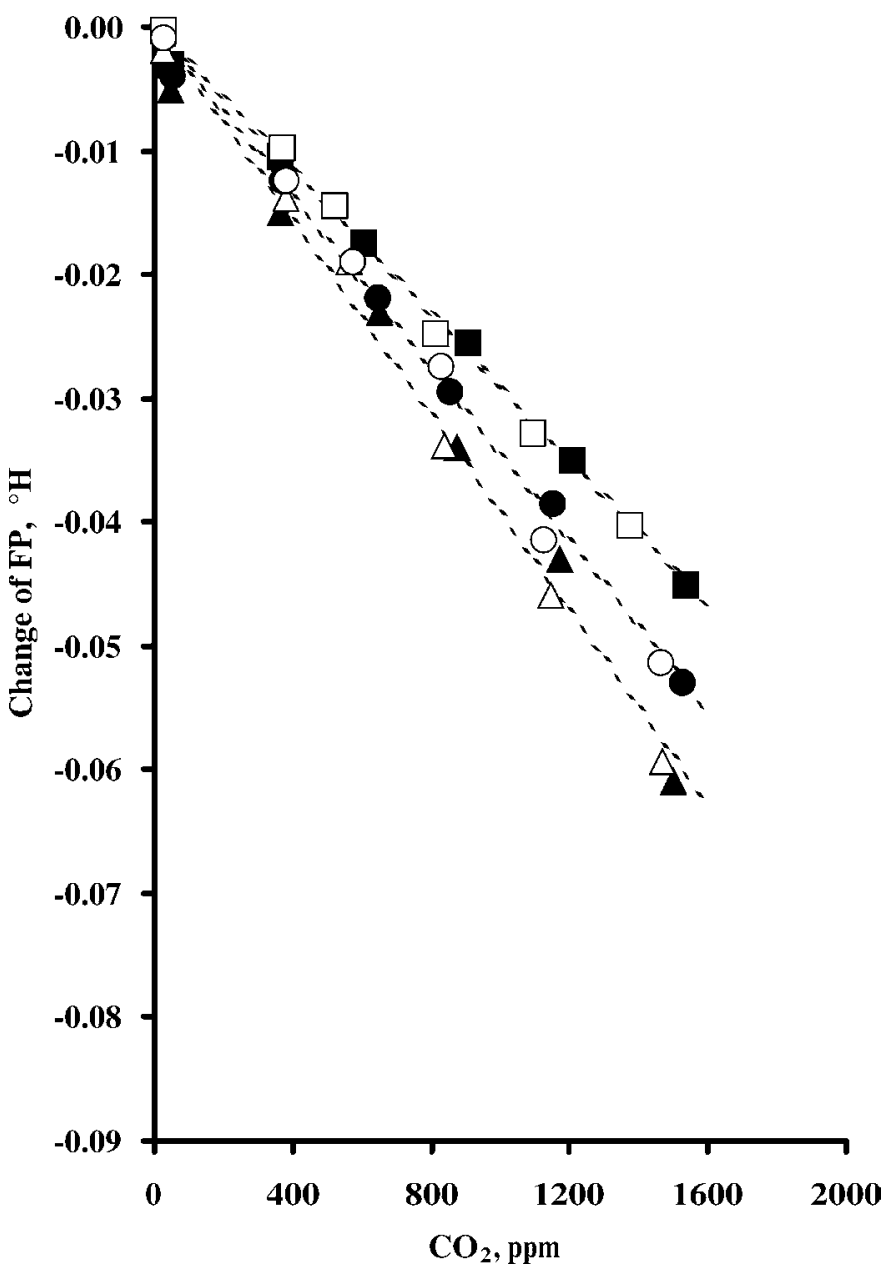

Figure 2. Change of freezing point (FP) in milks with $0 \%(\square, \square)$, $3 \%(\bullet, \bigcirc)$, and $6 \%(\boldsymbol{\Delta}, \triangle)$ serum protein upon $\mathrm{CO}_{2}$ addition. The solid and open symbols represent data from replication 1 and 2, respectively. The dotted lines are the least-square linear regression lines for each serum protein level.

about $32.7 \mathrm{mg} / 100 \mathrm{~g}$ milk. Typically, the total calcium concentration in milk is $30 \mathrm{mM}$, of which $20 \mathrm{mM}$ is associated with casein micelle (Holt, 1997). Assuming a $2.4 \% \mathrm{CN}$ concentration in milk (Swaisgood, 1985), CN-bound calcium is estimated to be about $33 \mathrm{mg} / \mathrm{g}$ $\mathrm{CN}$. Therefore, the increase in calcium in milk was mostly contributed by colloidal calcium bound to $\mathrm{CN}$. The calcium that was bound to $\mathrm{CN}$ was about 6.1 times the amount of calcium that was bound to SP (i.e., 5.3 $\mathrm{mg} / \mathrm{g} \mathrm{SP}$ ).

Without carbonation, the $\mathrm{pH}\left(0^{\circ} \mathrm{C}\right)$ of $\mathrm{CN} 2.4(\mathrm{pH}$ 6.97), CN4.8 (pH 6.96), and CN7.2 ( $\mathrm{pH} 6.96$ ) were similar (Table 5). Due to the presence of ionizable side groups and bound minerals, milk proteins, both $\mathrm{CN}$ and $\mathrm{SP}$, can raise the $\mathrm{pH}$ of a UF permeate. The $\mathrm{pH}$ of the UF permeate from skim milk with no SP or CN was 6.74 at $0^{\circ} \mathrm{C}$ (Table 2). The $\mathrm{pH}$ of milk permeate will increase to an equilibrium level at which a further increase of milk protein concentration will not cause a further increase in milk $\mathrm{pH}$. The equilibrium $\mathrm{pH}$ was probably already reached for CN2.4 and, therefore, increasing $\mathrm{CN}$ content further did not affect milk $\mathrm{pH}$ at $0^{\circ} \mathrm{C}$ (Table 5). This was in contrast to observations from experiment 1, where increasing SP from 0 to $6 \%$ continuous increased $\mathrm{pH}$ to a level similar to the $\mathrm{pH}$ of CN2.4 (Table 2). The protein concentration at which an equilibrium $\mathrm{pH}$ was reached in milk depended on the type of protein being added. This is not surprising because of the differences in protein ionizable side groups and the differences in protein bound minerals between $\mathrm{CN}$ and SP.

pH at $0^{\circ} \boldsymbol{C}$. The ANOVA found (Table 6) a significant influence of treatment (i.e., $\mathrm{CN}$ concentration) on the $\mathrm{pH}$ of milks with different $\mathrm{CO}_{2}$ concentrations. Statistical terms (Table 6) treatment, $\mathrm{CO}_{2}$ linear $\times$ treatment, and $\mathrm{CO}_{2}$ quadratic $\times$ treatment were all significant $(P$ $<0.01$ ). The effect of $\mathrm{CN}$ concentration can be seen in Figure 3: at the same $\mathrm{CO}_{2}$ concentration, the extent of $\mathrm{pH}$ reduction was less in milk with a higher $\mathrm{CN}$ concentration. This is similar to the effect observed for $\mathrm{SP}$ concentration. A milk with a higher $\mathrm{CN}$ concentration showed a greater resistance to $\mathrm{pH}$ change, indicating its higher buffering capacity. The higher the $\mathrm{CO}_{2}$ concentration, the greater the difference in $\mathrm{pH}$ (i.e., significant interaction effects) among CN2.4, CN4.8, and CN7.2 (Figure 3).

Casein is a major contributor to the buffering capacity of milk (Srilaorkul et al., 1989; Lucey et al., 1993), thus increasing $\mathrm{CN}$ concentration is expected to increase the buffering capacity of milk. Increasing $\mathrm{CN}$ concentration also leads to higher concentration of CCP that is associated with the native $\mathrm{CN}$ micelles. The presence of CCP is unique to $\mathrm{CN}$. Decreasing milk $\mathrm{pH}$ causes a progressive solublization of micellar CN, CCP, and other colloidal salts from CN micelles into the serum phase (Dalgleish and Law, 1989; Law and Leaver, 1998). Dissociated $\mathrm{CN}$ and colloidal salts in the water phase of milk provide negatively charged groups, such as phosphates, that can be combined with hydrogen ions produced by the dissociation of $\mathrm{H}_{2} \mathrm{CO}_{3}$, further providing resistance to the $\mathrm{pH}$ reduction effect of $\mathrm{CO}_{2}$.

Freezing point. Treatment (i.e., CN concentration) had a significant effect on milk FP, and the statistical terms (Table 6) for treatment and $\mathrm{CO}_{2}$ linear $\times$ treatment were significant $(P<0.01)$. FP decreased linearly with increasing $\mathrm{CO}_{2}$ concentration $(P<0.01)$, and at the same $\mathrm{CO}_{2}$ concentration, $\mathrm{FP}$ depression was greater for milk with a higher $\mathrm{CN}$ concentration (Figure 4). The regression slope for CN2.4 was similar to a previously reported value for skim milk $\left(-4.207 \times 10^{-5}\right.$, Ma and Barbano, 2002). Increasing $\mathrm{CN}$ content produced a 


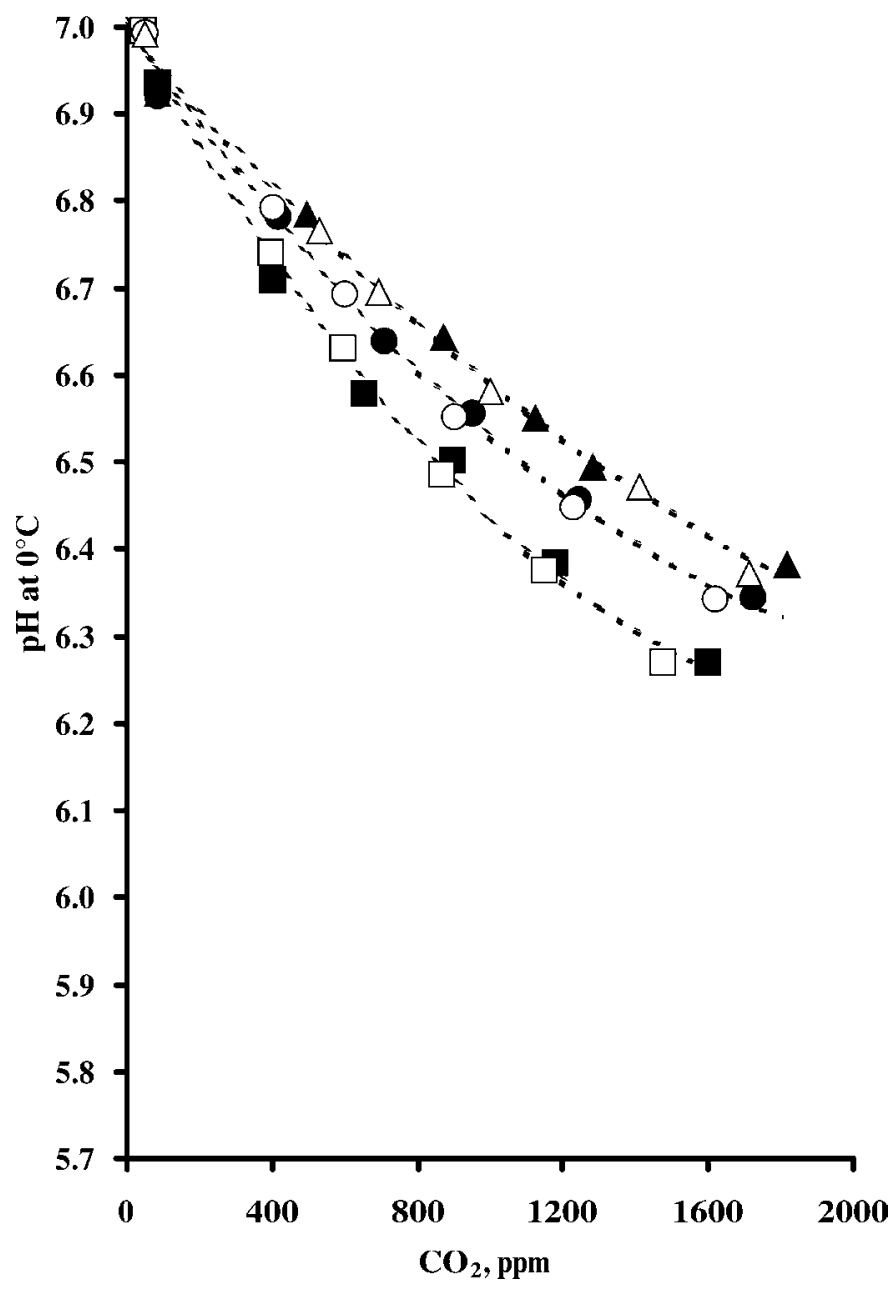

Figure 3. $\mathrm{pH}\left(0^{\circ} \mathrm{C}\right)$ of milk with $2.4 \%(\boldsymbol{\square}, \square), 4.8 \%(\bullet, \bigcirc)$, and $7.2 \%(\boldsymbol{\Lambda}, \triangle) \mathrm{CN}$ upon $\mathrm{CO}_{2}$ addition. The solid and open symbols represent data from replication 1 and 2 , respectively. The dotted lines are the least-square second order polynomial regression lines for each CN level.

more negative slope for FP depression upon $\mathrm{CO}_{2}$ addition (Table 4 and Figure 4).

With the lowering of milk $\mathrm{pH}$ due to $\mathrm{CO}_{2}$ addition, micellar calcium-phosphate and other colloidal salts begin to dissociate, contributing to an increased concentration of solute in the serum phase of milk (Dalgleish and Law, 1989; Gevaudan et al., 1996). Based on results from both experiments 1 and 2, in CN2.4, CN4.8, and CN7.2, the decrease of FP could be contributed by four sources of increasing solute concentration: (1) carbonic acid and its dissociation products, (2) shifts in the degree of association of soluble mineral aggregates, (3) solublized SP-bound minerals, and (4) solublized CNassociated CCP and other colloidal minerals.

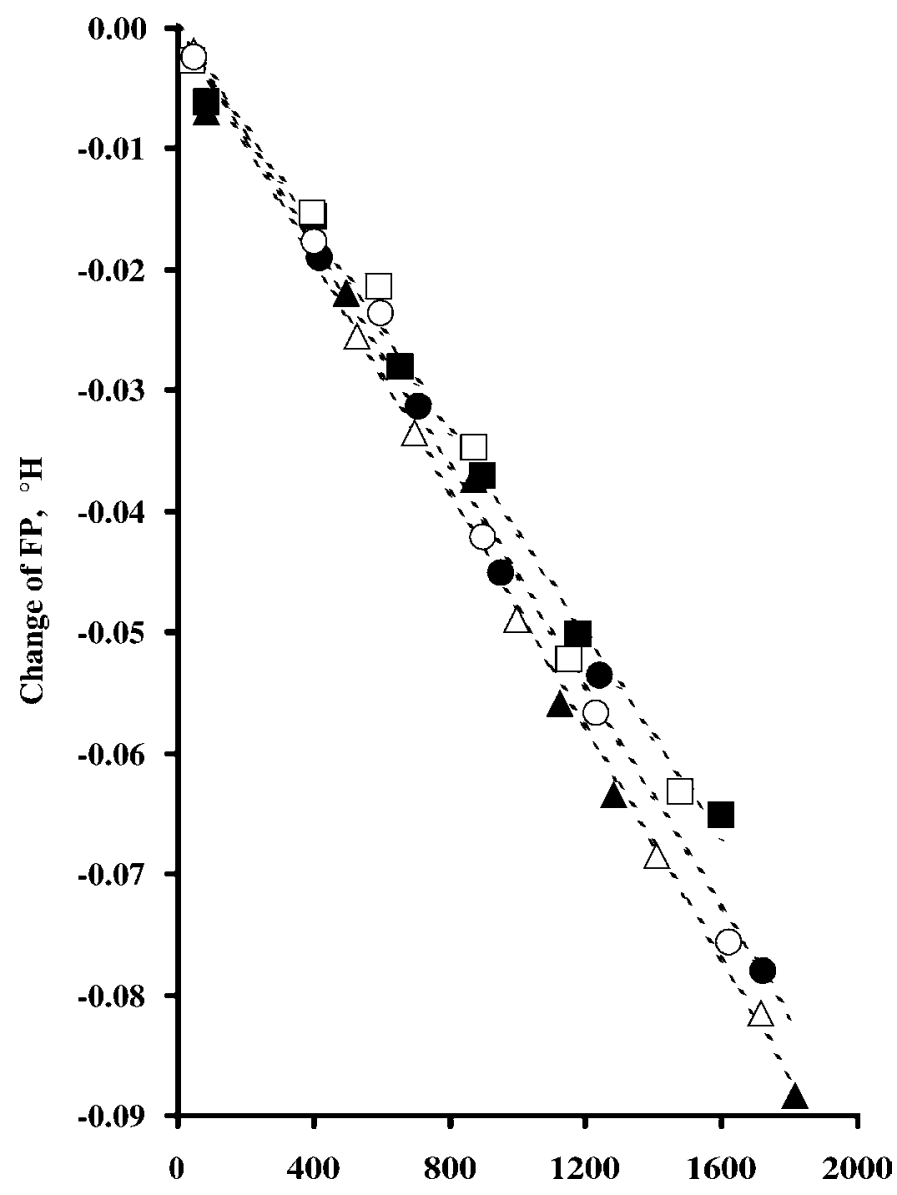

Figure 4. Change of freezing point (FP) in milks with $2.4 \%$ ( $\square$, $\square), 4.8 \%(\bullet, \bigcirc)$, and $7.2 \%(\boldsymbol{\Delta}, \triangle) \mathrm{CN}$ upon $\mathrm{CO}_{2}$ addition. The solid and open symbols represent data from replication 1 and 2 , respectively. The dotted lines are the least-square linear regression lines for each CN level.

\section{Impact of the Aqueous Phase Properties on Milk pH and FP}

Protein type. Both the SP3 and CN2.4 had 3\% TP in the fat-free portion of the milk (Tables 2 and 5). Instead of $3 \% \mathrm{SP}$ in SP3, there were $2.4 \% \mathrm{CN}$ plus $0.6 \%$ $\mathrm{SP}$ in $\mathrm{CN2.4}$. The higher calcium and ash content in the CN2.4 milk compared with the SP3 milk was expected because of the higher level of bound minerals associated with CN. Upon carbonation, CN2.4 exhibited more ( $P$ $<0.05$ ) resistance to $\mathrm{pH}$ decrease than SP3 (Figures 1 and 3). Therefore, the buffering capacity of CN2.4 was greater than that of SP3, even though the two milks had the same TP content (i.e., 3\%). Upon carbonation, there was a greater $(P<0.05)$ extent of FP depression for the CN2.4 milk than the SP3 milk as reflected by a more negative slope for the FP depression curve for the CN2.4 milk (Figures 2 and 4). Thus, with increasing $\mathrm{CO}_{2}$ concentration, the increase in solute concentration 
Table 5. Mean $(\mathrm{n}=2)$ composition, initial $\mathrm{CO}_{2}$ concentration, $\mathrm{pH}$ at $0^{\circ} \mathrm{C}$, and freezing point $(\mathrm{FP})$ of the three milks with increasing $\mathrm{CN}$ concentration in experiment 2.

\begin{tabular}{lccc}
\hline Parameters & $\mathrm{CN} 2.4$ & $\mathrm{CN} 4.8$ & $\mathrm{CN7.2}$ \\
\hline $\mathrm{CO}_{2}, \mathrm{ppm}$ & 64 & 66 & 66 \\
$\mathrm{pH}$ at $0^{\circ} \mathrm{C}(\mathrm{lsd}=0.03)$ & 6.97 & 6.96 & 6.96 \\
$\mathrm{FP},{ }^{1} \mathrm{H}^{1}(\mathrm{lsd}=0.038)$ & -0.551 & -0.561 & -0.570 \\
Total solids, \% (lsd = 2.70) & $9.86^{\mathrm{b}}$ & $12.35^{\mathrm{ab}}$ & $14.80^{\mathrm{a}}$ \\
Calcium, mg/100 g milk (lsd = 9.99) & $104.2^{\mathrm{c}}$ & $178.7^{\mathrm{b}}$ & $252.5^{\mathrm{a}}$ \\
$\mathrm{Ash} \%(\mathrm{lsd}=0.08)$ & $0.71^{\mathrm{c}}$ & $0.93^{\mathrm{b}}$ & $1.14^{\mathrm{a}}$ \\
$\mathrm{NPN}{ }^{2}, \%$ & 0.20 & 0.20 & 0.20 \\
$\mathrm{CN}$ in the fat-free portion, \% (lsd = 0.09) & $2.40^{\mathrm{c}}$ & $4.71^{\mathrm{b}}$ & $6.99^{\mathrm{a}}$ \\
SP in the fat-free, CN-free portion, \% (lsd = 0.29) & 0.60 & 0.60 & 0.64 \\
Lactose in the fat-free, CN-free, and SP-free portion, \% (lsd =0.22) & 5.27 & 5.25 & 5.24 \\
\hline
\end{tabular}

${ }^{\mathrm{a}, \mathrm{b}, \mathrm{c}}$ Means within the same row with different superscripts differ $(P<0.05)$.

${ }^{1}{ }^{\circ} \mathrm{H}=$ degrees Hortvet.

${ }^{2} \mathrm{NPN}=$ nonprotein nitrogen $\times 6.38$

in the skim portion of milk was greater in CN2.4 than in SP3. Changes in buffering capacity and mineral content due to a change in protein type at the same protein concentration had an influence on the extent of $\mathrm{pH}$ decrease and FP depression produced in milk when $\mathrm{CO}_{2}$ was added.

Validity of using $\mathrm{pH}$ as an estimate of $\mathrm{CO}_{2}$ concentration. Currently, low levels of $\mathrm{CO}_{2}$ are added to some dairy foods to inhibit microbial growth. The antimicrobial effect of $\mathrm{CO}_{2}$ is related to the amount of $\mathrm{CO}_{2}$ dissolved in the aqueous phase of a food (Fernandez et al., 1997; Devlieghere et al., 1998) and is independent of the $\mathrm{pH}$ reduction effect of $\mathrm{CO}_{2}$ (King and Mabbitt, 1982). The correlation between milk $\mathrm{pH}$ and $\mathrm{CO}_{2}$ concentration has been used as an indirect method for $\mathrm{CO}_{2}$ determination in milk (King and Mabbitt, 1987). Such correlation is only valid for milks with a similar fat content and a similar skim portion composition. The temperature of $\mathrm{CO}_{2}$ injection, milk fat content, and milk fat type can affect how much of the total dissolved $\mathrm{CO}_{2}$ will be dissolved in the skim portion of milk (Ma and
Barbano, 2002). Once $\mathrm{CO}_{2}$ is dissolved in the skim portion, the buffering capacity of the components in the skim portion will affect the extent of $\mathrm{pH}$ decrease (Figures 1 and 3). Therefore, when the buffering capacity of the skim portion of milk is changed, either by an increase of protein concentration or by an alteration of $\mathrm{CN}$ to $\mathrm{SP}$ ratio, a simple $\mathrm{pH}$ measurement does not provide an accurate estimate of the amount of $\mathrm{CO}_{2}$ dissolved in the skim portion. Therefore, if $\mathrm{CO}_{2}$ is going to be used in a dairy food as an antimicrobial agent and a specific target concentration of $\mathrm{CO}_{2}$ is needed, then $\mathrm{CO}_{2}$ concentration should be measured directly and not estimated by decrease in $\mathrm{pH}$.

Using $\mathrm{CO}_{2}$ as a processing aide. In addition to the use of $\mathrm{CO}_{2}$ as an antimicrobial agent, another application of the $\mathrm{CO}_{2}$ technology in the dairy industry could be the use of $\mathrm{CO}_{2}$ as an acidulent to decrease milk $\mathrm{pH}$ and to release protein bound minerals, such as calcium, into the serum phase. For example, preacidification of milk with $\mathrm{CO}_{2}$ in cheesemaking has been explored (McCarney et al., 1995; St-Gelais et al., 1997; Cham-

Table 6. Sum of squares (SS) and probabilities $(P)$ from the ANOVA of $\mathrm{pH}\left(0^{\circ} \mathrm{C}\right)$ and freezing point $(\mathrm{FP})$ data in experiment 2 . The treatment was CN concentration: $2.4,4.8$, and $7.2 \%$.

\begin{tabular}{|c|c|c|c|c|}
\hline \multirow[b]{2}{*}{ Independent variable } & \multicolumn{2}{|c|}{$\begin{array}{c}\mathrm{pH} \text { at } 0^{\circ} \mathrm{C} \\
\mathrm{SSM}^{1}=1.613 \text { Model } \mathrm{R}^{2}=0.996\end{array}$} & \multicolumn{2}{|c|}{$\begin{array}{c}\text { FP } \\
\text { SSM }=0.0285 \\
\text { Model } \mathrm{R}^{2}=0.996\end{array}$} \\
\hline & $\mathrm{SS}^{2}$ & $P$ & SS & $P$ \\
\hline Replicate & 0.025 & & 0.0015 & \\
\hline Treatment (i.e., CN concentration) & 0.061 & $<0.01$ & 0.0036 & $<0.05$ \\
\hline Replicate $\times$ treatment & $<0.001$ & & 0.0001 & \\
\hline $\mathrm{CO}_{2}$ linear & 1.493 & $<0.01$ & 0.0200 & $<0.01$ \\
\hline $\mathrm{CO}_{2}$ quadratic & 0.037 & $<0.01$ & & \\
\hline $\mathrm{CO}_{2}$ linear $\times$ treatment & 0.014 & $<0.01$ & 0.0001 & $<0.01$ \\
\hline $\mathrm{CO}_{2}$ quadratic $\times$ treatment & 0.013 & $<0.01$ & & $\cdots$ \\
\hline Error $(\mathrm{E})$ & 0.007 & & 0.0001 & \\
\hline
\end{tabular}

${ }^{1} \mathrm{SSM}=$ Sum squares of model.

${ }^{2} \mathrm{SS}=$ Sum squares of individual factors. 
pagne et al., 1998). Using $\mathrm{CO}_{2}$ as a processing aide is promising because once the desired and irreversible changes in milk are achieved, $\mathrm{CO}_{2}$ can be removed from the final product by applying a vacuum. In the case of cheesemaking, $\mathrm{CO}_{2}$ is simply lost during further processing. Another attractive aspect for using $\mathrm{CO}_{2}$ is that $\mathrm{CO}_{2}$ is a GRAS (Generally Recognized As Safe) food additive (21CFR184.1240, 2001).

Upon $\mathrm{CO}_{2}$ addition, there is a solublization of proteinbound minerals as a result of $\mathrm{pH}$ reduction, and an increase in the level of solublized minerals can either cause problems or create benefits during dairy processing, depending on the situation. For example, a lower $\mathrm{pH}$ and an increased soluble calcium of milk due to $\mathrm{CO}_{2}$ addition may increase fouling in a heat exchanger during pasteurization of milk. Decreased $\mathrm{pH}$ and increased SP concentration have been shown to increase the extent of thermal aggregation, especially $\beta$-LG and CN during heating (Smits and van Brouwershaven, 1980; Corredig and Dalgleish, 1996; Beaulieu et al. 1999). Heating-induced association between SP and $\mathrm{CN}$ modifies the physiochemical properties of the $\mathrm{CN}$ micelles, and the modified CN micelles may exhibit different behavior in dairy food systems compared with the native $\mathrm{CN}$ micelles.

As the dairy industry starts to bring various processing technologies and ingredients together to create novel products, it is important to understand and control the behavior of milk-derived beverages with altered protein level, protein type, and mineral content created through membrane technology. The knowledge gained in the current study may facilitate future research on $\mathrm{CO}_{2}$ as a processing aide to achieve favorable changes in the physiochemical properties of dairy foods.

\section{CONCLUSIONS}

Increasing SP or $\mathrm{CN}$ content increased milk buffering capacity and protein-bound mineral content. At the same added $\mathrm{CO}_{2}$ concentration at $0^{\circ} \mathrm{C}$, a milk with a higher SP or a higher $\mathrm{CN}$ content had more resistance to $\mathrm{pH}$ change and a greater extent of FP depression. At constant TP content, milk with a higher proportion of $\mathrm{CN}$ had a higher buffering capacity and provided more resistance to $\mathrm{pH}$ decrease and a larger decrease in $\mathrm{FP}$ when $\mathrm{CO}_{2}$ was added at $0^{\circ} \mathrm{C}$. Once $\mathrm{CO}_{2}$ was dissolved in the skim phase of a milk, the extent of $\mathrm{pH}$ reduction and FP depression depended on protein concentration and protein type (i.e., $\mathrm{CN}$ and $\mathrm{SP}$ ).

\section{ACKNOWLEDGMENTS}

The authors thank Tom Burke, Maureen Chapman, Bob Kaltaler, Laura Landolf, Joanna Lynch, Noriko
Misawa, Brandon Nelson, Ammar Olabi, and Pat Wood for technical assistance. We also thank the Northeast Dairy Foods Research Center (Ithaca, NY) and the New York State Milk Promotion Board (Albany, NY) for financial support.

\section{REFERENCES}

Association of Official Analytical Chemists, International. 2000. Official Methods of Analysis. 17th ed. AOAC, Arlington, VA.

Barbano, D. M., M. A. Rudan, and Y. Ma. 2000. Sensory characteristics of milks with different casein to serum protein ratios. J. Dairy Sci. 83(suppl. 1): 89.

Beaulieu, M., Y. Pouliot, and M. Pouliot. 1999. Thermal aggregation of whey protein in model solutions as affected by casein/whey protein ratios. J. Food Sci. 64:776-780.

Brandsma, R. L., and S. S. H. Rizvi. 1999. Depletion of whey proteins and calcium by microfiltraiton of acidified skim milk prior to cheese making. J. Dairy Sci. 82:2063-2069.

Britten, M., and Y. Pouliot. 1996. Characterization of whey protein isolate obtained from milk microfiltration permeate. Lait 76:255-265.

Brooks, I. B., G. A. Luster, and D. G. Easterly. 1970. A procedure for the rapid determination of the major cations in milk by atomic absorption spectrophotometry. Atomic Adsorption Newsletter 9(4):93-94.

Champagne, C. P., D. St-Gelais, and A. de Candolle. 1998. Acidification rates and population ratios of lactic starters in carbonated milk. Lebensmittel-Wissenschaft \& Technologie. 32:100-106.

Code of Federal Regulations (CFR). 2001. Title 21. Food and Drugs. Chapter 1. Food and Drug Administration Dept. of Health and Human Serv. Part 184. Direct Food Substance Affirmed as Generally Recognized as Safe. Pages 487-488.

Corredig, M., and D. G. Dalgleish. 1996. Effect of temperature and $\mathrm{pH}$ on the interactions of whey proteins with casein micelles in skim milk. Food Res. Int. 59:49-55.

Dalgleish, D., and A. J. R. Law. 1989. pH-induced dissociation of bovine casein micelles II. Mineral solubilization and its relation to casein release. J. Dairy Res. 56:727-735.

Daniels, J. A., R. Krishnamurthi, and S. S. H. Rizvi. 1985. A review of the effects on microbial growth and food quality. J. Food Prot. 48:532-537.

Devlieghere, F., J. Debevere, and J. van Impe. 1998. Concentration of carbon dioxide in the water-phase as a parameter to model the effect of a modified atmosphere on microorganisms. Int. J. Food Microbiol. 43:105-113.

Fernandez, P., S. M. George, C. C. Sills, and M. W. Peck. 1997. Predictive model of the effect of $\mathrm{CO}_{2}, \mathrm{pH}$, temperature and $\mathrm{NaCl}$ on the growth of Listeria monocytogenes. Int. J. Food Microbiol. 37:37-45.

Gevaudan, S., A. Lagaude, B. R. de la Funte, and J. L. Cuq. 1996. Effect of treatment by gaseous carbon dioxide on the colloidal phase of skim milk. J. Dairy Sci. 79:1713-1721.

Gill, C. O. 1988. The solubility of carbon dioxide in meat. Meat Sci. 22:65-71.

Glantz, S. A., and B. K. Slinker. 2001. Multicollinearity and what to do about it. Pages 185-187 in Primer of Applied Regression \& Analysis of Variance. 2nd ed. McGraw-Hill, Inc. New York, NY.

Holt, C. 1997. The milk salts and their interaction with casein. Pages 233-255 in Advanced Dairy Chemistry. 2nd ed. P. F. Fox, ed. Vol. 3. Lactose, Water, Salts, and Vitamins. Chapman \& Hall, London, UK.

Hotchkiss, J. H. and E. Lee. 1996. Extending shelf-life of dairy products with dissolved carbon dioxide. Eur. Dairy Mag. 8(3):16, $18-19$.

Hotchkiss, J. H., J. H. Chen, and H. Lawless. 1999. Combined effects of carbon dioxide and barrier films on microbial and sensory change in pasteurized milk. J. Dairy Sci. 82:690-695.

King, J., and L. A. Mabbitt. 1982. Preservation of raw milk by the addition of carbon dioxide. J. Dairy Res. 49:439-447. 
King, J. S., and L. A. Mabbitt. 1987. The use of carbon dioxide for the preservation of milk. Pages 35-43 in Preservatives in the Food, Pharmaceutical, and Environmental Industries. Technical Series, Society for Applied Bacteriology. No. 22. Blackwell Scientific Publications, Boston, MA.

Law, A., and J. Leaver. 1998. Effects of acidification and storage of milk on dissociation of bovine casein micelles. J. Agric. Food Chem. 46:5008-5016.

Lucey, J., B. Hauth, C. Gorry, and P. F. Fox. 1993. The acid-base buffering properties of milk. Milchwissenschaft 48:268-272.

Ma, Y., D. M. Barbano, J. H. Hotchkiss, S. Murphy, and J. M. Lynch. 2001. Impact of $\mathrm{CO}_{2}$ addition to milk on selected analytical testing methods. J. Dairy Sci. 84:1959-1968.

Ma, Y., and D. M. Barbano. 2003. Impact of temperature of $\mathrm{CO}_{2}$ addition on the $\mathrm{pH}$ and FP of milks and creams. J. Dairy Sci. 86:(in press: JDS-02-431).

Marshall, R. T. ed. 1993. Standard Methods for the Examination of Dairy Products. 16th ed. Am. Publ. Health Assoc., Inc., Washington, DC.

McCarney, T., W. M. A. Mullan, and M. T. Rowe. 1995. Effect of carbonation of milk on cheddar cheese yield and quality. Milchwissenschaft 50:670-674.

Neocleous, M., D. M. Barbano, and M. A. Rudan. 2002a. Impact of low concentration factor microfiltration on milk component recovery and cheddar cheese yield. J. Dairy Sci. 85: 2415-2424.

Neocleous, M., D. M. Barbano, and M. A. Rudan. 2002b. Impact of low concentration factor microfiltration on composition and aging of cheddar cheese. J. Dairy Sci. 85:2425-2437.
Patocka, G., P. Jelen, and M. Kalab. 1993. Thermostability of skim milk with modified casein/whey protein content. Int. Dairy J. 3:35-48.

Quiñones, H. J., D. M. Barbano, and L. G. Phillips. 1997. Influence of protein standardization by ultrafiltration on the viscosity, color, and sensory properties of skim and $1 \%$ milk. J. Dairy Sci. 80:3142-3151.

Quiñones, H. J., D. M. Barbano, and L. G. Phillips. 1998. Influence of protein standardization by ultrafiltration on the viscosity, color, and sensory properties of 2 and $3.3 \%$ milks. J. Dairy Sci. 81:884-894.

Rashed, M. A., N. M. Mckenna, and A. S. Mehanna. 1986. Effect of carbondioxide on improving the keeping quality. J. Soc. Dairy Tech. 39:62-64.

SAS software version 8.02, 1999-2001. SAS Inst., Inc., Cary, NC.

Singh, H., O. J. McCarthy, J. A. Lucey. 1997. Physico-chemical properties of milk. Pages 470-518 in Advanced Dairy Chemistry. 2nd ed. P. F. Fox, ed. Vol. 3. Lactose, Water, Salts, and Vitamins. Chapman \& Hall, London, UK.

Smits, P., and J. H. van Brouwershaven. 1980. Heat-induced association of $\beta$-lactoglobulin and casein micelle. J. Dairy Res. 47:313-325.

Srilaorkul, S., L. Ozimek, F. Wolfe, and J. Dziuba. 1989. The effect of ultrafiltration on physicochemical properties of retentate. Can. Inst. Food Sci. Technol. J. 22:56-62.

St-Gelais, D., C. P. Champagne, and G. Bélanger. 1997. Production of cheddar cheese using milk acidified with carbon dioxide. Milchwissenschaft 52:614-618.

Swaisgood, H. E. 1985. Characteristics of edible fluids of animal origin: milk. Pages 799-801 in Food Chemistry. O. R. Fennema, ed. 2nd ed. Marcel Dekker, Inc., New York, NY. 